Supportive Care in Cancer Patients 


\section{Antibiotics and Chemotherapy}

Vol. 50 


\section{Supportive Care in Cancer Patients}

\section{Recent Developments}

Volume Editors Meinolf Karthaus, Hannover

Arnold Ganser, Hannover

9 figures, and 38 tables, 2000

KARGER $\begin{aligned} & \text { Basel } \cdot \text { Freiburg } \cdot \text { Paris } \cdot \text { London } \cdot \text { New York } \\ & \text { New Delhi } \cdot \text { Bangkok } \cdot \text { Singapore } \cdot \text { Tokyo } \cdot \text { Sydney }\end{aligned}$ 


\title{
Antibiotics and Chemotherapy
}

\section{Meinolf Karthaus}

\section{Arnold Ganser}

Abteilung Hämatologie/Onkologie

Medizinische Hochschule Hannover

Carl-Neuberg-Strasse 1

D-30625 Hannover

\author{
Library of Congress Cataloging-in-Publication Data \\ Supportive care in cancer patients:recent developments / volume editors, Meinolf Karthaus, Arnold Ganser. \\ (Antibiotics and chemotherapy, vol. 50) \\ Includes bibiographical references and index. \\ 1. Cancer - Treatment - Complications - Treatment. 2. Cancer - Palliative treatment. \\ 3. Antineoplastic agents - Side effects. I. Karthaus, Meinolf. II. Antibiotics and chemotherapy; v.50 \\ [DNLM: 1. Neoplasms - complications. 2. Neoplasms - therapy. 3. Palliative Care. \\ QZ 266 S9589 2000] \\ RC270.8.S88 2000 \\ 616.99'406-dc21 \\ ISSN $0066-4758$ \\ ISBN 3-8055-6910-6
}

Bibliographic Indices. This publication is listed in bibliographic services, including Current Contents ${ }^{\circledR}$ and Index Medicus.

Drug Dosage. The authors and the publisher have exerted every effort to ensure that drug selection and dosage set forth in this text are in accord with current recommendations and practice at the time of publication. However, in view of ongoing research, changes in government regulations, and the constant flow of information relating to drug therapy and drug reactions, the reader is urged to check the package insert for each drug for any change in indications and dosage and for added warnings and precautions. This is particularly important when the recommended agent is a new and/or infrequently employed drug.

All rights reserved. No part of this publication may be translated into other languages, reproduced or utilized in any form or by any means electronic or mechanical, including photocopying, recording, microcopying, or by any information storage and retrieval system, without permission in writing from the publisher.

(c) Copyright 2000 by S. Karger AG, P.O. Box, CH-4009 Basel (Switzerland)

www.karger.com

Printed in Switzerland on acid-free paper by Reinhardt Druck, Basel

ISBN 3-8055-6910-6 


\section{Contents}

\section{Preface}

1 Changing Epidemiology of Bacterial Infection in Neutropenic Patients with Cancer

Carratalà, J.; Gudiol, F. (Barcelona)

10 Serum and Plasma Parameters in Clinical Evaluation of Neutropenic Fever

Südhoff, Th. (Bochum); Giagounidis, A. (Düsseldorf); Karthaus, M. (Hannover)

20 Antimicrobial Therapy in Neutropenic Patients

Egerer, G. (Heidelberg); Karthaus, M. (Hannover); Goldschmidt, H.;

Ho, A.D. (Heidelberg)

26 Interventional Once-Daily Administration of Ceftriaxone in Leukemia and Lymphoma Patients with Febrile Neutropenia

Karthaus, M. (Hannover); Südhoff, Th. (Düsseldorf); Egerer, G. (Heidelberg);

Fenchel, K. (Giessen); Kämpfe, D. (Lüdenscheid); Ritter, J. (Münster);

Franke, A. (Magdeburg); Heil, G. (Ulm); Peters, G.; Jürgens, H. (Münster)

37 Ceftriaxone and Cefotaxime Are Equally Effective in the Treatment of Neutropenic Fever

Cornely, O.A.; Salzberger, B.; Bethe U.; Seifert, H.; Fätkenheuer, G.; Diehl, V.; Schrappe, M. (Köln)

47 Outpatient Treatment of Cancer Patients with Fever and Neutropenia Karthaus, M. (Hannover); Egerer, G. (Heidelberg); Jürgens, H. (Münster)

59 Current Serological and Molecular Methods in the Diagnosis of Systemic Infections with Candida sp. and Aspergillus sp. in Immunocompromised Patients with Hematological Malignancies Buchheidt, D.; Skladny, H.; Baust, C.; Hehlmann, R. (Heidelberg) 
69 Antifungal Prophylaxis in Neutropenic Patients with Hematologic Malignancies

Böhme, A. (Frankfurt); Karthaus, M. (Hannover), Hoelzer, D. (Frankfurt)

79 Treatment of Systemic Fungal Infections in Patients with Hematologic Malignancies

Böhme, A. (Frankfurt); Karthaus, M. (Hannover)

94 Clinical Use of Hematopoietic Growth Factors Seipelt, G. (Frankfurt)

106 Recombinant Human Erythropoietin in the Treatment of Cancer Stilgenbauer, F.; Egerer, G. (Heidelberg); Karthaus, M. (Hannover); Goldschmidt, H.; Ho, A.D. (Heidelberg)

115 New Strategies in the Treatment and Prophylaxis of Chemo- and Radiotherapy-Induced Oral Mucositis

Rosenthal, C. (Essen); Karthaus, M.; Ganser, A. (Hannover)

133 Central Venous Catheter-Related Complications

Salwender, H.-J.; Egerer, G.; Bach, A.; Hahn, U.; Goldschmidt, H.;

Ho, A.D. (Heidelberg)

144 Cytotoxic Drug Extravasation

Fenchel, K. (Giessen); Karthaus, M. (Hannover)

149 Anticoagulant Prophylaxis and Therapy in Patients with Cancer von Depka Prondzinski, M.; Karthaus, M.; Ganser, A.; Barthels, M. (Hannover)

159 Quality of Life Assessment - Problems and Goals Meran, J.G. (Vienna); Karthaus, M. (Hannover); Ludwig, H. (Vienna)

171 Treatment of Chemotherapy-Induced Emesis Egerer, G.; Hegenbart, U.; Salwender, H.-J.; Goldschmidt, H.; Ho, A.D. (Heidelberg)

184 Diarrhea and Constipation

Hartmann, J.T.; Bokemeyer, C. (Tübingen)

189 Author Index

190 Subject Index 


\section{a \\ Preface}

Anticancer therapy has been considerably intensified over the last decade in an attempt to increase the cure rate and to prolong overall survival. In addition, the proportion of elderly patients included in intensive therapy protocols has increased. These changes in the therapeutic approach to cancer patients have been made possible by a constant development in supportive care. Although there is no exact definition of supportive care, the term is very broad and includes care of cancer manifestations, prevention and management of side effects following therapeutic interventions, and psychological support.

The text attempts to cover the most frequent problems of supportive care in detail, especially prevention, diagnosis and treatment of infections, adverse events of the gastrointestinal tract, or the treatment of cytotoxic drug extravasation with special emphasis on the recently introduced cytotoxic agents. Other chapters deal with the rational use of hematopoietic growth factors for the reversal of disease- or treatment-related neutropenia, anemia and thrombocytopenia. Additional issues include anticoagulant prophylaxis and therapy as well as the assessment of quality of life. All the chapters have been written by experts in the field of oncological supportive care who have addressed the issues from the viewpoint of the practising physician.

Supportive care requires an interdisciplinary approach. The present book is therefore designed to provide up-to-date information for oncologists as well as general physicians, nurses, pharmacists, and all those providing care to tumor patients. It is our hope that it optimizes supportive care for all cancer patients allowing them to cope with the adverse effects of modern-day therapy.

M. Karthaus

A. Ganser 